\title{
Identifikasi Polimorfisme rs72626594 Gen BMP7 pada Penderita Karies Gigi
}

\section{Identification of rs72626594 BMP7 Gene Polymorphism in Dental Caries Patients}

\author{
Mitayani Purwoko ${ }^{1}$, Dientyah N Anggina ${ }^{2}$ \\ ${ }^{1}$ Departemen Biologi Kedokteran Fakultas Kedokteran Universitas Muhammadiyah Palembang \\ ${ }^{2}$ Departemen IImu Kesehatan Masyarakat Fakultas Kedokteran Universitas Muhammadiyah Palembang
}

\begin{abstract}
ABSTRAK
Karies gigi adalah demineralisasi substansi anorganik pada permukaan gigi akibat bakteri atau kebiasaan makan dan minum. Karies gigi dapat timbul akibat adanya kerentanan genetik maupun akibat faktor lingkungan. Beberapa penelitian menunjukkan adanya asosiasi antara polimorfisme gen tertentu dengan timbulnya karies gigi, salah satunya adalah gen Bone Morphogenetic Protein 7 (BMP7). Penelitian ini bertujuan untuk mengidentifikasi polimorfisme rs72626594 gen $B M P 7$ pada penderita karies gigi di Palembang. Penelitian ini merupakan penelitian observasional deskriptif. Data yang dikumpulkan merupakan data primer yang diperoleh langsung dari 15 subjek yang dipilih dari populasi umum di kota Palembang melalui anamnesis, pemeriksaan fisik, dan pemeriksaan biologi molekuler. Anamnesis dan pemeriksaan fisik dilakukan oleh dokter gigi untuk mendiagnosis riwayat karies gigi. DNA diambil dengan cotton bud steril dengan mengusap bagian dalam masing-masing pipi sebanyak tiga kali. DNA dipurifikasi menggunakan kit buatan pabrik. DNA kemudian diamplifikasi menggunakan PCR untuk kemudian di-sequencing. Dari hasil pemeriksaan biologi molekuler diperoleh seluruh sampel kasus dalam penelitian ini memiliki alel $G$ yaitu alel wildtype. Hasil penelitian ini menunjukkan bahwa subjek penderita karies gigi memiliki alel yang umum terdapat di populasi. Meskipun BMP7 dikenal sebagai gen yang berperan dalam pembentukan gigi namun saat ini belum dapat dipastikan apakah BMP7 benar terlibat dalam kejadian karies gigi atau tidak. Oleh karena itu perlu dilakukan penelitian lanjutan mengenai asosiasi antara polimorfisme dengan kejadian karies gigi.
\end{abstract}

Kata Kunci: BMP7, genetik, karies gigi, polimorfisme, rs72626594

\begin{abstract}
Dental caries is demineralization of inorganic substances on the surface of the teeth due to bacteria or eating and drinking habits. Dental caries can arise due to genetic vulnerability or environmental factors. Several studies have shown an association between certain gene polymorphisms and the emergence of dental caries, one of which is the Bone Morphogenetic Protein 7 (BMP7) gene. The purpose of this study was to identify the polymorphism of rs 72626594 BMP7 gene in dental caries patients. This was a descriptive observational study. The data collected were primary data obtained directly from 15 subjects through history taking, physical examination, and molecular biology examination. Historical and physical examination were performed by dentists to diagnose the history of dental caries. DNA was taken with sterile cotton buds by rubbing the inside of each cheek three times. DNA was purified using a factory-made kit. DNA was then amplified using PCR and then sequenced. From the results of molecular biology examination, all subjects had G allele which is wildtype allele. The results of this study indicated that subjects with dental caries have alleles that are common in the population. Although BMP7 is known as a gene that plays a role in tooth formation, it remains uncertain whether BMP7 is properly involved in the incidence of dental caries or not. It is necessary to do further research to find the association between BMP7 polymorphism and the incidence of dental caries.
\end{abstract}

Keywords: BMP7, dental caries, genetics, polymorphism, rs72626594

Korespondensi: Mitayani Purwoko. Departemen Biologi Kedokteran Fakultas Kedokteran Universitas Muhammadiyah Palembang, Jl. K.H. Balqhi (Talang Banten), 13 Ulu, Palembang 30263 Tel. (0711)520045 Email: mitayani.dr@gmail.com

DOI: http://dx.doi.org/10.21776/ub.jkb.2019.030.03.9 


\section{PENDAHULUAN}

Kesehatan mulut adalah suatu hal yang sangat penting karena apabila terganggu, maka dapat mengganggu aktivitas sehari-hari. Salah satu gangguan mulut adalah karies gigi yang merupakan demineralisasi substansi anorganik pada permukaan gigi akibat bakteri. Kebiasaan makan makanan manis, makanan lengket, dan minum susu menjadi salah satu penyebab karies gigi, karena itu kebiasaan penduduk Palembang makan pempek dan cuka bila tidak disertai perawatan gigi yang baik dapat meningkatkan risiko karies gigi (1).

Kesehatan gigi termasuk karies gigi menjadi permasalahan kesehatan penting. Prevalensi nasional masalah gigi dan mulut adalah 25,9\% (2) sementara ditemukan prevalensi karies gigi pada anak usia di bawah 3 tahun di Brazil sebesar $64,3 \%$. Sebagian besar dari anak-anak yang menderita karies (53,5\%) menunjukkan kondisi karies gigi yang parah. Karies gigi yang tidak ditangani berhubungan erat dengan penurunan kualitas hidup penderita dan keluarganya (3). Dalam sebuah penelitian skala besar di Jepang, ditemukan data bahwa didapatkan kaitan antara menyusui selama 6-7 bulan pertama kehidupan dengan peningkatan risiko mengalami karies gigi pada usia 30 bulan bila dibandingkan dengan bayi yang diberi susu formula saja. Namun, kaitan menjadi tidak lagi signifikan seiring pertambahan usia anak (4). Tingkat keparahan kerusakan gigi dinyatakan dalam indeks DMF-T, yaitu penjumlahan dari gigi yang rusak namun masih dapat ditambal (D), gigi yang hilang karena dicabut (M), dan gigi yang telah ditambal (F) (5). Prevalensi nasional indeks DMF-T adalah 4,6, sementara indeks DMF$T$ di Sumatera Selatan lebih tinggi yaitu 5,3 (2).

Karies gigi dapat timbul akibat adanya kerentanan genetik maupun akibat faktor lingkungan sehingga termasuk penyakit multifaktorial. Shaffer dkk. melakukan penelitian genome wide association study (GWAS) dan menemukan asosiasi bermakna antara karies gigi pada bagian anterior mandibula dengan gen $L Y Z L 2$, yaitu sebuah gen yang mengkode agen antibakteri. Mereka juga menemukan asosiasi bermakna antara karies gigi di bagian tengah dengan gen $A J A P 1$, sebuah gen yang kemungkinan berperan dalam pembentukan gigi. Selain kedua gen tersebut, mereka juga menemukan kemungkinan asosiasi antara karies gigi dengan gen $A B C G 2, P K D 2$, the dentin/bone SCPP sub-family, EDNRA, TJFBR1, NKX2-3, IFT88, TWSG1, IL17D, dan SMAD7 (6). Sebuah penelitian di China menemukan hubungan antara gen ENAM dan TNF- dengan karies gigi pada anak-anak. Variasi gen ENAM rs3796703 CT kemungkinan meningkatkan risiko menderita karies gigi, sementara variasi gen TNFrs1800629 AG kemungkinan memberi perlindungan terhadap timbulnya karies gigi (7).

Pembentukan gigi dipengaruhi oleh gen tertentu, salah satunya adalah gen Bone Morphogenetic Protein 7 (BMP7). BMP7 diketahui berperan dalam terjadinya karies gigi terutama polimorfisme rs72626594 (dengan nilai $p=3 \times 10^{-8}$ ). Produk dari gen ini merupakan faktor pertumbuhan yang penting bagi mineralisasi jaringan. Hasil penelitian meta-analisis mengenai Genome-wide association study (GWAS) menunjukkan asosiasi yang signifikan antara rs72626594 dengan penyakit karies gigi (8). Namun Romanos dkk. menemukan asosiasi antara karies gigi primer dengan polimorfisme gen BMP2, tidak dengan gen BMP7 (9).

Karies gigi adalah penyakit multifaktorial, maka ada kemungkinan peranan faktor genetik selain faktor makanan khas Palembang yang lengket dan manis yang menyebabkan tingginya angka kejadian karies gigi di Sumatera Selatan. Oleh karena itu penelitian ini dilakukan dengan tujuan untuk menemukan peranan genetik pada karies gigi dengan cara mengidentifikasi polimorfisme rs72626594 Bone Morphogenetic Protein 7. Pengetahuan tentang adanya polimorfisme dapat membantu mengurangi angka kejadian penyakit dengan pemahaman masyarakat yang lebih baik terkait kerentanan genetik.

\section{METODE}

Penelitian ini merupakan penelitian observasional deskriptif. Penelitian dilakukan pada bulan Maret-Agustus 2018. Pengambilan subjek penelitian dilakukan di Palembang dan pemeriksaan biologi molekuler dilakukan di Laboratorium Fakultas Kedokteran Universitas Gadjah Mada Yogyakarta. Populasi penelitian ini adalah penduduk kota Palembang yang menderita karies gigi. Besar sampel sebanyak 15 orang diambil secara random dari masyarakat umum dengan kriteria inklusi laki-laki dan perempuan, memiliki gigi permanen dengan karies gigi, dan bersedia menandatangani informed consent. Kriteria eksklusi dari penelitian ini adalah penderita karies gigi yang memiliki darah keturunan dari luar Indonesia seperti Arab, Eropa, Afrika, dan India.

Pengambilan sampel DNA dilakukan dengan menggunakan cotton bud steril yang diapuskan ke mukosa pipi subjek penelitian. Setelah itu dilakukan ekstraksi DNA dari sel mukosa pipi dengan menggunakan kit FavorPrep Tissue Genomic DNA Extraction Mini Kit. Pemeriksaan biologi molekuler dilakukan dengan menggunakan alat Polymerase Chain Reaction (PCR) yang bertujuan untuk mengamplifikasi sekuens rs72626594 yaitu (10):

\section{TTGGGGGCCG TACCCGCAGA GACCT[A/G]TGCT CCCCAGAGAC AGTGGATGTC}

Primer yang digunakan adalah forward 5'gcccaacctcaggattcctc- $3^{\prime}\left(\mathrm{Tm}=60,1^{\circ} \mathrm{C}\right)$ dan reverse $5^{\prime}$ tctcaaacgcctgacctcag- $3^{\prime}\left(\mathrm{Tm}=59,7^{\circ} \mathrm{C}\right)$. Profil PCR yang digunakan adalah denaturasi $95^{\circ} \mathrm{C}$ selama 5 detik, gradient 1 detik, annealing $59^{\circ} \mathrm{C}$ selama 1 detik, elongasi $72^{\circ} \mathrm{C}$ selama 5 detik, dan hold $4^{\circ} \mathrm{C}$. Besar produk PCR yang dihasilkan adalah $414 \mathrm{bp}$. Produk PCR diperiksa dengan metode sequencing untuk menentukan alel pada rs72626594. Reagen PCR yang digunakan untuk satu reaksi adalah $\mathrm{dH}_{2} \mathrm{O}$ $8,5 \mu \mathrm{l}$, Go Taq green MM 12,5 $\mu \mathrm{l}$, primer forward $10 \mu \mathrm{M} 1 \mu \mathrm{l}$, primer reverse $10 \mu \mathrm{M}, 1 \mu \mathrm{l}$, dan DNA $2 \mu \mathrm{l}$. Produk PCR kemudian di-sequencing dengan metode Sanger. Hasil sequencing dibaca dengan software Snapgene Viewer.

\section{HASIL}

Penelitian ini menggunakan 15 orang sebagai subjek penelitian (Tabel 1) yang sebagian besar perempuan (60\%). Dari sisi usia tidak ada subjek yang berusia kurang dari 17 tahun, dan sebagian besar berusia antara 17-45 tahun.

Tabel 1. Karakteristik subjek penelitian

\begin{tabular}{ccr}
\hline Karakteristik & Frekuensi (orang) & Persentase (\%) \\
\hline Jenis kelamin & & \\
Perempuan & 9 & 60,0 \\
Laki-laki & 6 & 40,0 \\
Total & 15 & 100,0 \\
\hline
\end{tabular}


Tabel 1. Karakteristik subjek penelitian (Lanjutan)

\begin{tabular}{|c|c|c|}
\hline Karakteristik & Frekuensi (orang) & Persentase (\%) \\
\hline \multicolumn{3}{|l|}{ Usia } \\
\hline$<17$ tahun & 0 & 0,0 \\
\hline 17-25 tahun & 8 & 53,3 \\
\hline 26-35 tahun & 2 & 13,3 \\
\hline $36-45$ tahun & 3 & 20,0 \\
\hline 46-55 tahun & 1 & 6,7 \\
\hline$>55$ tahun & 1 & 6,7 \\
\hline Total & 15 & 100,0 \\
\hline
\end{tabular}

Proses ekstraksi DNA dari mukosa pipi menghasilkan DNA yang berkualitas untuk dilanjutkan ke proses PCR diikuti proses sequencing. Hasil sequencing salah satu sampel memperoleh hasil seperti pada Gambar 1:
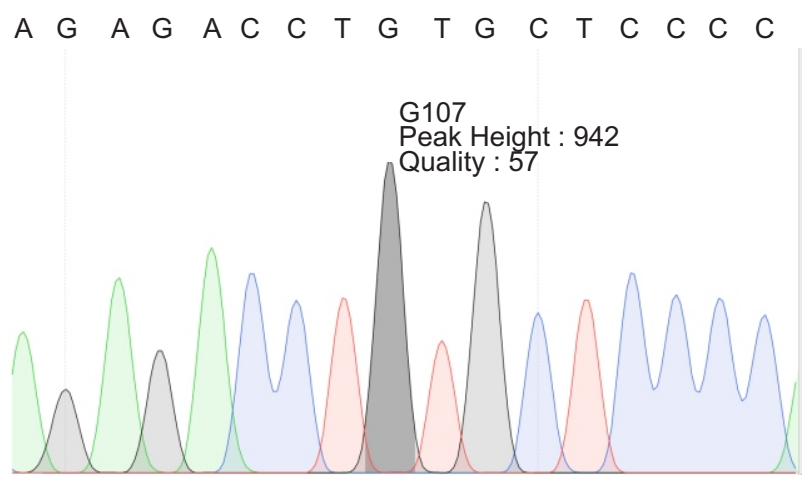

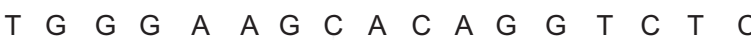

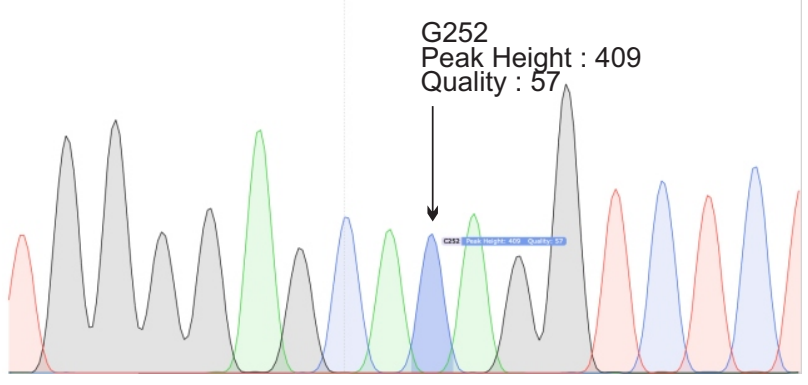

Gambar 1. Hasil sequencing

Keterangan:

Gambar atas: dengan primer forward menunjukkan alel G (kurva hitam berlabel)

Gambar bawah: dengan primer reverse menunjukkan alel C (kurva biru berlabel)

Hasil sequencing pada Gambar 1 menunjukkan bahwa subjek penelitian memiliki alel G/G pada rs72626594 gen BMP7. Hasil sequencing pada kelima belas subjek penelitian menunjukkan bahwa semua sampel memiliki alel $\mathrm{G}$ pada posisi rs72626594 gen BMP7, tidak ada yang memiliki alel A atau G/A.

\section{DISKUSI}

Tidak banyak publikasi mengenai gen BMP7 pada karies gigi. Penelitian ini adalah penelitian pertama di Indonesia yang meneliti distribusi alel rs72626594 gen BMP7 pada penderita karies gigi. Dalam penelitian ini, semua subjek penelitian memiliki alel G/G pada rs72626594 gen BMP7 (100\%). Hasil penelitian ini sejalan dengan frekuensi alel G pada referensi sebesar $99,022 \%$. Hal ini menunjukkan bahwa alel yang dimiliki adalah alel wildtype, yaitu alel yang banyak terdapat di populasi. Polimorfisme rs72626594 terletak di kromosom 20q13,31 pada posisi 56960465 berdasarkan GRCh38.p7. Alel referensi pada rs72626594 adalah alel $\mathrm{G}$ dan alel mutan adalah alel A dengan frekuensi alel 0,978\% (11).

Bone Morphogenetic Proteins adalah bagian dari superfamili Transforming Growth Factor Beta (TGF beta) (12). BMP7 merupakan protein homodimer berukuran 35kDa yang dikaitkan dengan proses penghantaran sinyal, seperti jalur SMAD, jalur mitogen-activated protein kinase (MAPK), dan jalur phosphoinositol 3-kinase (PI3K) (13). Ligand dari BMP7 akan berikatan dengan reseptor TGF beta yang akan menginduksi aktivasi faktor transkripsi SMAD. Aktivasi faktor transkripsi SMAD akan meregulasi ekspresi gen (9). Protein ini berperan dalam perkembangan tulang, mata, ginjal dan jaringan lemak coklat. Selain itu, protein ini akan membantu proses penyembuhan tulang yang patah $(10,14)$. Studi sebelumnya mennjukkan apabila tikus dikondisikan untuk kehilangan gen BMP7 maka akan terjadi defek kraniofasial termasuk defek pada gigi dan glandula saliva. BMP7 diketahui memiliki peranan dalam meningkatkan pertumbuhan dan perbaikan jaringan yang mengalami mineralisasi, misalnya tulang (8).

Sebuah percobaan stimulasi pertumbuhan epitel gigi dan sel mesenkim gigi insisor hewan pengerat dengan BMP4, BMP7, dan Wnt3a pada 4-5 hari setelah kelahiran menunjukkan adanya pertumbuhan jaringan yang menyerupai jaringan enamel dan dentin dalam bentuk dua lapisan terintegrasi (15). Meskipun protein dari gen BMP7 berperan dalam perkembangan tulang, namun ternyata beberapa SNP pada gen BMP7 tidak berkaitan dengan densitas mineral tulang ataupun fraktur osteoporosis pada wanita Chinese yang telah mengalami menopause (16). Produk dari gen BMP2, BMP4, dan BMP7 diekspresikan di primary enamel knot namun peranannya dalam hal tersebut belum dapat dijelaskan secara rinci (17).

Dalam Oral Health 2020 yang telah disepakati oleh World Health Organization (WHO), Federation Dental Internasional (FDI) dan International Association for Dental Research (IADR), dinyatakan bahwa tujuan utama penanganan karies gigi di Indonesia adalah mengurangi gigi yang hilang akibat dicabut karena menderita karies gigi (M) dengan kelompok target yaitu kelompok usia 18 tahun, 35-44 tahun, dan 65-74 tahun. Semakin tinggi usia seseorang maka semakin parah karies giginya (5). Hal ini menunjukkan bahwa kemungkinan faktor lingkungan berperan besar dalam timbulnya karies gigi seiring pertambahan usia.

Meskipun hasil penelitian ini masih belum dapat memastikan apakah ada hubungan sebab akibat antara variasi genetik pada gen $B M P 7$ dengan timbulnya karies gigi, namun penelitian epidemiologi molekuler tetap perlu dilakukan untuk mempelajari gen penyebab suatu penyakit dengan harapan suatu hari nanti akan dapat mengurangi angka kesakitan (18).

Penelitian ini menyimpulkan bahwa penderita karies gigi yang diperiksa memiliki alel wildtype pada rs72626594 gen 
BMP7. Sebagai studi awal dengan jumlah sampel terbatas, hasil ini dilanjutkan dengan studi kasus kontrol untuk meperkuat bukti asosiasi faktor genetik dan karies gigi.

\section{UCAPAN TERIMA KASIH}

Ucapan terima kasih kami sampaikan kepada Direktorat Riset dan Pengabdian Masyarakat, Direktorat Jenderal

\section{DAFTAR PUSTAKA}

1. Widayati N. Faktoryang Berhubungan dengan Karies Gigi pada Anak Usia 4-6 Tahun. Jurnal Berkala Epidemiologi. 2014; 2(2): 196-205.

2. Badan Penelitian dan Pengembangan Kesehatan. Riset Kesehatan Dasar 2013. Jakarta: Kementerian Kesehatan RI. 2013; hal. 110

3. Fernandes IB, Pereira TS, Souza DS, Ramos-Jorge J, Marques LS, and Ramos-Jorge ML. Severity of Dental Caries and Quality of Life For Toddlers and Their Families. Pediatric Dentistry. 2017; 39(2): 118-123.

4. Kato T, Yorifuji T, Yamakawa M, et al. Association of Breast Feeding With Early Childhood Dental Caries: Japanese Population-Base Study. BMJ Open. 2015; 5(3): 1-9.

5. Notohartojo IT dan Ghani L. Pemeriksaan Karies Gigi pada Beberapa Kelompok Usia oleh Petugas dengan Latar Belakang Berbeda di Provinsi Kalimantan Barat. Buletin Penelitian Kesehatan. 2015; 43(4): 257-264.

6. Shaffer JR, Feingol E, Wang X, et al. GWAS of Dental Caries Pattern in the Permanent Dentition. Journal of Dental Research. 2013; 92(1): 38-44.

7. Wang M, Qin M, and Xia B. The Association of Enamelin, Lactoferrin, and Tumour Necrosis Factor Alpha Gene Polymorphisms with High Caries Susceptibility in Chinese Children Under 4 Years Old. Archives of Oral Biology. 2017; 80: 75-81.

8. Morrison J, Laurie CC, Marazita ML, et al. Genomewide Association Study of Dental Caries in the Hispanic Communities Health Study/Study of Latinos (HCHS/SOL). Human Molecular Genetics. 2016; 25(4): 807-816.

9. Romanos HF, Antunes LS, Lopes LB, et al. BMP2 is Associated with Caries Experience in Primary Teeth. Caries Research. 2015; 499(4): 425-433.
Penguatan Riset dan Pengembangan Kementerian Riset, Teknologi, dan Pendidikan Tinggi atas pembiayaan penelitian ini berupa hibah Penelitian Dosen Pemula Simlitabmas 2018, staf Laboratorium Biologi Molekuler Fakultas Kedokteran Universitas Gadjah Mada dan staf Laboratorium Biomedik Fakultas Kedokteran Universitas Muhammadiyah Palembang atas bantuannya dalam pengolahan material DNA.

10. National Center for Biotechnology Information. Bone Morphogenetic Protein 7. (Online) 02 Oktober 2018 di https://www.ncbi.nlm.nih.gov/gene/655. [diakses tanggal 20 Oktober 2018].

11. Wang RN, Green J, Wang Z, et al. Bone Moprhogenetic Protein (BMP) Signaling in Development and Human Diseases. Genes \& Diseases. 2014; 1(1): 87-105.

12. Saito K, Takahashi K, Asahara M, et al. Effects of Usag1 and Bmp7 Deficiencies on Murine Tooth Morphogenesis. BMC Developmental Biology. 2016; 16(14): 1-10.

13. Oxburgh L. Control of the Bone Morphogenetic Protein 7 Gene in Developmental and Adult Life. Current Genomics. 2009; 10(4): 223-230.

14. Jian N, Zhou J, Chen M, et al. Postnatal Epithelium and Mesenchyme Stem/Progenitor Cells in Bioengineered Amelogenesis and Dentinogenesis. Biomaterials. 2014; 35(7): 2172-2180.

15. Gao LH, Li SS, Shao C, et al. BMP7 Gene Polymorphisms are Not Associated with Bone Mineral Density or Osteoporotic Fractures in Postmenopausal Chinese Women. Acta Pharmacologica Sinica. 2016; 37(8): 1076-1082.

16. Graf D, Malik Z, Hayano S, and Mishina Y. Common Mechanisms in Development and Disease: BMP Signaling in Craniofacial Development. Cytokine \& Growth Factor Reviews. 2016; 27:129-139.

17. National Center for Biotechnology Information. rs72626594. (Online) 22 Maret 2018 di https://www.ncbi.nlm.nih.gov/snp/?term=rs726265 94. [diakses tanggal 20 Oktober 2018].

18. Sundari, Aulani'am, S Wahono D, dan Widodo MA. Faktor Risiko Non Genetik dan Polimorfisme Promoter Region Gen CYP11B2 Varian T(0344C) Aldosterone Synthase pada Pasien Hipertensi Esensial di Wilayah Pantai dan Pegunungan. Jurnal Kedokteran Brawijaya. 2013; 27(3): 169-177. 